\title{
DE MALEISCHE VERSIE VAN DEN ARABISCHEN POPULAIREN ROMAN VAN DEN HELD SAIF IBN DZII'L-JAZAN.
}

\author{
DOOR
}

Dr. PH. S. VAN RONKEL.

De zgn. „Fabulae Milesiae”, romantische verhalen, 1001-Nachtachtige vertellingen, populaire tot de Arabische volkslectuur te rekenen producten van fantasie, mogen niet tot de klassieke letterkunde of door literatoren op prijs gestelde geschriften gerekend worden, toch zijn ze in breede kringen gezocht, al ware 't slechts omdat ze, gemakkelijker te lezen dan de specimina van hooger litterair genre, aan den smaak van het groote publiek voldoen, en, door vertellers van beroep in nachtelijke uren voorgedragen, op groote belangstelling kunnen, althans konden, rekenen, vooral als ze in verband staan met het leven van den Profeet of zijne onmiddellijke voorgangers en opvolgers.

De bekendste vertegenwoordigers van dit genre in het Arabisch zijn Antar, az-Zahir, Aboe Zaid, Doe'l-Himmah, Saif Ibn Dzīll-Jazan e.a., van enormen omvang, in met poesie afwisselend prosa, van fantastischen inhoud, vol avonturen van helden, daemonen, gevechten, schakingen, ontmoetingen met bovennatuurlijke wezens, duels met verleiders van na tallooze geburtenissen gevangen en eindelijk bevrijde bruiden, liefdesscènes in tooverpaleizen en door magie in het leven geroepen steden en wonder-regionen.

Laatst genoemd geschrift is kortelijk vertaald en toegelicht door R. Paret, Sirat Saif Ibn Dhi Jazan, ein Arabischer Volksroman, 1924, een werk, waaraan in de De ut sche Literaturzeitung, 1925, 46 Jahrgang, bl. 966-967 door R. Hartmann en in Anthropos, 1925, deel XX, bl. 783-784 door O. Spies welverdiende hulde is gebracht. Terecht prijzen beiden het geduld van den bewerker van de inhoudsopgave. Zelfs de auteur van den Berlijnschen H. S.-catalogus, de onvermoeibare Ahlwardt, die zeker tegen geen arbeid heeft opge- 
zien, getuigt van den ingewikkelden inhoud: „Die einzelnen und zum Theil viel verschlungenen Abenteuer können nicht angegeben werden ; sie sind oft genug ermüdender Art”. De korte inhoud was slechts uit handschriftencatalogi, vooral van dien van Ahlwardt, Berlijn, en enkele verwijzingen in andere geschriften bekend; de kennis van de in den afschrikwekkend breedvoerigen roman bevatte materie, is, zooals gezegd, aan Paret's analyse te danken ${ }^{1}$ ).

Hij gebruikte de editie in vier deelen van Kairo van 1322-1904/05, die voor de nachtelijke voorlezingen uit zeventien afdeelingen samengesteld is. Later, in 1924, is aldaar (Boelak) nog eene editie in drie deelen verschenen. Van handschriften heeft de bewerker geen gebruik gemaakt; die vindt men vermeld in den cat. cod. Ar. Leiden, $2^{\circ}$ ed. no. 1680a (Gotha, Lund, Londen, Parijs, Ambrosiana, Leipzig), waarbij nog te voegen: Berlin (Ahlwardt, VIII, 72-79), en C. Brockelmann, Geschichte der Arab. Literatur, II, 62 en suppl. 64. De gewone titel is Sïrat Saif Dzō'l-Jazan, mèt artikel, en als schrijver wordt genoemd Abō'l-Ma'ālî̀ (die ook als auteur van den roman van Amir Hamzah wordt vermeld), van welken naam merkwaardigerwijze niet door Paret is melding gemaakt.

Dat er verscheidene handschriften van dezen heldenroman bestaan, en vooral het feit dat er méér dan ééne uitgave van verschenen is, duiden op populariteit in bepaalde kringen; trouwens de door Paret aangehaalde plaats uit Lane's Manners and Customs of the modern Egyptians duidde daarop reeds in voldoende mate.

Hoe degelijk de Arabische kant van den roman ook is behandeld, en hoe rijk de „Nachweis der benützen Literatur” ook is - Sprenger's Leben und Lehre des Mohammed, III, bl. 448 had daar ook nog genoemd kunnen worden, maar niet alle ,einschlägige” loci kunnen bij zulk een onderwerp vermelding vinden —, van het bestaan eener Maleische versie heeft Paret geen melding gemaakt, wat trouwens niet tot zijn onderwerp behoorde.

De tendez: de overwinning van de Semieten op de Chamieten kan den Maleischen bewerker niet getroffen hebben, wel: de glorie van den naderenden islam, de heenwijzing naar de grootheid van den Profeet en de zijnen, de aankondiging van de alles overwinnende

1) Van zijne hand zijn ook: Der Ritterroman von 'Umar an Nu'män und seine Stellung zur Sammilung von 1001 Nacht; die legendäre Maghāzī-Literatur, Arabische Dichtungen über die Muslemischen Kriegszüge zu Muhammed's Zeit; Zur Frauenfrage in der Arabisch-islamischen Welt; Früharabische Liebesgeschichten. 
Leer, en vooral: het karakter yan het geschrift: de eindelooze verwikkelingen, de wonderverhalen, de tooverij en bovennatuurlijke 'gebeurtenissen, de schakingen, hinderlagen, veldslagen, uitreddingen, in 't kort het welbekende schablon der uitgebreide hikajat's, waaraan de Maleische literatuur zoo rijk is. Ons kan die overdaad der feiten, gepaard aan eenvormigheid van den opzet, matig bekooren, maar bij Maleiers, of Maleisch-lezende Javanen en anderen, had dit genre groote populariteit. Geen wonder dat deze hypertrophische roman een bewerker in het Maleisch gevonden heeft !

Of die bewerking ooit werkelijk populair is geweest, is moeilijk te zeggen, in elk geval bestaan er verscheidene handschriften van, en is ze te Singapoera uitgegeven, waaruit althans blijkt dat er belangstelling voor bestond. De HSS zijn vermeld in den Bataviaschen Catalogus, bl. 260-267, vier stuks, alle van hetzelfde formaat uit de verzameling-von Dewall. Dit zou kunnen wijzen op veel aanbod aan den „resident voor de Maleische taal” $H$. von Dewall, die de geoffreerde specimina heeft laten copieeren, doch daaruit behoeft nog niet te blijken dat het verhaal werkelijk veel bekendheid genoot. Het bestond, zoodat hiervan niet kan verondersteld worden dat het is gemaakt om aan de vraag uitgaande van de helpers des „,residents” te voldoen, gelijk menige hikajat, naar wel eens gefluisterd werd, zou zijn gecreëerd!

Ons interesseert de anteekening achter den tekst van het vierde exemplaar: dit geschrift is overgeschreven uit het manuscript van Tambi Hasan Bin Frṣ. b. Die Zuid-Indisch Moslim (tambi: de Tamil aanspreektitel vooral op Mohammedanen toegepast) bezat dus een tekst, en stond dien ter copieering af ; aan het geschrift werd zeker waarde gehecht.

Het eenige in andere verzamalingen bekende exemplaar is dat van de door H. C. Klinkert aangelegde collectie, no. 15; in den Supplement-Catalogu-Leiden, bl. 39, no. 98) wordt het een ,uit het Arabisch bewerkte roman" genoemd.

De Singapoerasche lithographie (Kol. Bibl. hs. 258) is van 1894, 2 dln., octavo, tesamen $344 \mathrm{bl}$; ze behoort tot het aantal Maleische teksten dat omstreeks 1898 door den heer B. Hoetink is aangekocht, en later door hem, nog vóórdat hij Secretaris van het Instituut was geworden, aan die instelling is ten geschenke gegeven voor de boekerij. De titel is: Hikajat_Da'l-Jazan; de tekst was eigendom van den drukker-uitgever Hadji Moehammad Aminn, die zijn werk heeft 
laten registreeren, waardoor het verboden werd het te laten herdrukken.

Dat het uit het Arabisch is bewerkt, staat niet vermeld; trouwens zulk een aanwijzing komt vrijwel nooit in dergelijke verhalen voor, wél in Mohammedaansche teksten, in ruimen zin genomen, n.l. zoowel religieuse werken als semi-kitābachtige geschriften, gelijk het Boek der Duizend Vragen e.d.

De vraag of het uit het Arabisch kán vertaald zijn is niet twijfelachtig. In de vroegere opvatting dat alles wat op het Islamische betrekking had uit het Arabisch moest zijn is door het feit dat groote romans als die van Hamzah den oom des Profeets, en Moehammed ibn al-Ḥanafijjah, zijn derden kleinzoon, die mèt Hasan en Hoesain als $d e$ martelaren des Islams beschouwd werd, niet uit die taal, maar uit het Perzisch vertaald waren, wijziging gebracht, maar er is nog vrij wat van deze Maleische materie dat ongetwijfeld op Arabische bronnen teruggaat. Boeken als de Hikajat Iskandar Dzō'l-Karnain (de Alexander-roman), de Hikajat Tamim ad-Dari, de Hikajat Moehammad Moekabil - resp. volgens T. J. v. Leeuwen's Utrechtsche dissertatie, mijn opstel in Versl. en Meded. v. Kon. Akad. v. Wet. Afd. Lett. $5^{\circ} \mathrm{r}$. dl. III, en eene mededeeling, niet gepubliceerd, van Dr. A. A. Cense - kunnen dat bewijzen. De auteur Abō'l-Ma'ālī wordt telkenmale genoemd, de stof is Arabisch, de geest was naar den smaak der Maleiers, en de Arabische tekst is bekend, terwijl geen Perzische versie vermeld wordt.

Wat betreft de alhier (Leiden) aanwezige Arabische materie, deze bestaat uit codex $1680^{1}$ ), gedateerd DO. 25 Sjawwāl 1259, het schrift is typisch Maghribi. Het eenigszins hoogdravende begin is: hadā kịtāb sīrat Saif Ibn Di'l-Yazan al-Ḥimyari al-Yamārī (sic.) wahuwa aĝāib wagarīb wa-siyar wa ahāēịt yasību lahā aṣ-ṣagīr, d.i. dit is het boek van het leven van Saif Ibn-Dzi’l-Yazan den Himyariet, den Jamaniet, nl. wonderen en vreemde dingen en geschiedenissen en verhalen waarvan de jeugd grijs wordt.

$\mathrm{Na}$ de doxologie volgt dan: kāna fīmā maḍā wa takaddama wasalafa min al-aḥādit (sic met artikel) al-umam as-sābiḳati annahu kāna mālikun min mulūki 'l-Yaman yusamma Dī'l-Jazan al-Himyarī min al-tataba'ati lahu ĝunūdun wa 'asākiru tarkabu rukūbatan .... wa kāna lahu waziruhu yusammā Yathțiib d.i.: in het verleden, hetgeen voorbij is en achter ons ligt, waren er gebeurtenissen van vroegere

1) $1680 \mathrm{a}$ bevat slechts een fragment. 
volken, ril. dat er een vorst van Jaman was genaamd Dzī'l-Yazan de Himjariet behoorende tot de toeba's, die een ontelbaar leger had van ruiters... en een 'wazir Yathrib geheeten.

Verschillend hiervan is het begin der Kaireensche editie, 1294 in $3 \mathrm{dln}$, in 17 djoez, welker titel is: Sïrat Fāris al-Jaman wamubīd 3 dln, in 17 djoez, welker titel is : Sïrat Färis Dahli'l-kufr wa'hl-mihan Saif Ibn al-Jaman wamubīd ahtî'l-Yazan. Hier is de doxologie nog lijke begin, wat letterlijke vertaling vrijwel onmogelijk maakt. Er wordt in vermeld, dat het verhaal gaat over den emier Saif Ibn Dzi’l-Yazan, den vernietiger van de ongeloovigen en den onderdrukkers in alle andere plaatsen en de verdelger der tooverijen en lagen; dat het wonderlijk is van wezen en noopt tot aanroeping van Allāh, die de geschiedenissen der voorvaderen heeft gesteld tot leering der nakomelingen, en de berichten der vroegere volkeren (wederom umam, meervoud van ummah) als richtsnoer voor de na hen komenden, enz. waarop een uitvoerig gebed om zegen volgt.

Eindelijk volgt kāala 'rrāwwi Abū'l-Ma'ālī; de verhaler van de sìrat abī'l-amșār wassaik an-nūl min ard 'l-Habašati ilā hadihi'ddiyār, die bericht dat er in oude tijden en vroegere perioden en tijdperken een vorst was van onvergelijkelijke kracht en macht (de overvloed van synoniemen is bezwaarlijk weer te geven !) ... de Himjariet DzūlYazan in het land Jemen, die een wazir had van groot verstand (volgt een reeks epitheta), die wijs was in alles, en de groote legers aanvoerde, en Jahrib heette. Hij nu had gelezen in oude boeken en groote krijgskronieken, en gevonden in het oude Testament en het Nieuwe en de geschriften van Ibrāhim den vriend Gods en in de Psalmen Davids: den naam van onzen Heer Moehammad uit het geslacht van Koeraisj. van de zonen Hāsjims, en in zijne beschrijving aangetroffen, dat hij den Islām en het Geloof zou openbaar maken en de godsdiensten der ongeloovigen afschaffen benevens alle rebellie op de geheele aarde. Toen hij nu (zegt de rārui) deze boeken had gelezen, en ontwaard had wat daarin stond van onwaarheid en waarheid, volgde hij deze en verzaakte gene, en geloofde in onzen Heer den Profeet en de overige Profeten en Gezanten, en wist dat zij de Waarheid bezaten, en volgde de Zekerheid, en behoorde tot de vrome dienaren Godes. Hij verborg zijn geloof voor al de zijnen, en niemand wist zijn islam, en zijn volgen der Profeten.

Dit was geheel in ,prose rimée”, een kunststijl, die in alle gesprekken, vooral tusschen vorst en wazir, toegepast wordt, waartoe de 
synoniemenrijke Arabische taal zich bij uitstek leent, maar die niet in eenige andere taal, ook niet in de Maleische, is weer te geven. Hierdoor is eene textueele vergelijking tusschen de Maleische versie en het Arabische origineel (voor zoover men daarvan spreken mag) onmogelijk. Doch uit deze beginpericope bleek reeds eene verwantschap tusschen beide bewerkingen, ook door overeenstemmend gebruik van enkele bepaalde woorden. Overigens is tekstvergelijking tusschen de uitvoerige Arabische redactie, en à fortiori van de Maleische versie daarmede, onbestaanbaar, omdat dit werk is bestemd voor voordracht van beroepsvertellers, ten gevolge waarvan elke uitgave, waartoe de hịkāyatī middelen heeft kunnen vinden, met behoud van de behandelde onderwerpen en volledige overlevering der materie, anderen vorm en anderen stijl heeft kunnen verkrijgen. Deze Arabische bewerking is geheel en al voor het gehoor, met haar berijmd prosa, haar woordenpraal, haar stijlhypertrophie, haar gezelschaps-entertainmentkarakter, en dat is in geen vertaling na te volgen, ergo: tekstvergelijking is uitgesloten, al blijft constateering van eendere termen (zooals ummat zie boven) mogelijk. Doch de tekst in den codex is sober, daar staat bv. alleen dat de wazir in de oude boeken had gelezen dat de Profeet als laatste der Profeten zou gezonden worden, dat hij in Hem geloofde vóór Zijne zending, en dat hij zulks voor een ieder, ook voor den vorst, verborgen hield.

In ons Maleische apparaat is de inleiding is HS.-Klinkert als volgt : wabihi nasta'īn bi'llāh 'alā ini hịkajat orang dahoeloe kala jang terlaloe sangat indah-indahnja daripada atas angin datang kebawah angin dan demikianlah tjeriteranja ditjerakan (sic) olèh orang jang empoenja hikajat ini; daarna eene nieuwe alinea met het geijkte begin: alkissah maka terseboetlah perkataannja daripada zamān dahoeloe kala maka adalah bahoeasanja pada masa itoe seorang orang radja daripada radja toebaa jang dahoeloe kala empoenjai kemoeliaän dan kebesaran dan kekerasan serta dengan empoenjaï ra'jat dan balatanteranja jang amat banjak jang tiada tepermenaï bilangannja itoe dan tiada bandingnja pada masa zamān itoe.... dan telah adalah radja itoe namanja Dzō'l-Jazan dan kediamannja didalam negeri Jaman dan adalah baginja soeatoe wazir jang ber'akal lagi bidjaksana dan tiada lagi bandingnja daripada masjrik datang kemagrib sjahadan maka namanja wazir itoe Jathrib....

Iets uitvoeriger en in het gebruik van enkele woorden iets dichter bij den Arabischen tekst staande is het begin der lithographie, nl. (na de lange doxologie): 
kemoedian daripada itoe telah berkata sjaich Abō'l-Màālī telah koedengar didalam kitab kebanjakan jang dengan tjerita jang 'adjãib jang terkarang didalamnja segala jang memberi gemar jang gharib bahoeasanja telah diseboetkan Allah.... maka olèh pada (sic) zamān dahoeloe kala daripada tjarita oemat (cfm. Arab. al-umam as-sābiḳah) dahoeloe kala bahoeasanja adalah pada masa zaman itoe soeatoe radja mempoenjaï keradjaan dan kemoeliaan dan kebesaran dan kegemaran serta dengan mempoenjaī ra'jat dan tentara jang amat banjak jang tiada dapat terbilang lagi dan tiada bandingnja lagi pada zaman itoe daripada segala radja-radja iaitoe daripada bangsa banī Chaibar at toebā'ah jang dichabarkan meréka antara segala machloek masjhoer namanja dan telah adalah radja itoe namanja Dzal-Jazan dan tempat kediamannja dalam negeri Jaman dan adalah baginja soeatoe wazir jang berakal dan bidjaksana tiadalah ada baginja banding dari masjrik dan magrib namanja wazir itoe Jathrib....

Van dezen wazir wordt verder verteld dat hij in boeken uit oude tijden had gelezen dat Allah eenmaal een spruit uit het geslacht der Hasjimieten, van den stam Koeraisj zou doen opstaan in Mekka, die alle godsdiensten zou vernietigen en den islam verheffen, en dat hij, zulks ontwaard hebbende, innerlijk in den Profeet geloofde, en met Allah's hulp zijne overtuiging voor al zijne volksgenooten wist te verbergen.

In het HS. staat deze laatste passage aldus opgeteekend:

maka adalah iaitoe telah menilik pada segala kitab jang dahoeloe kala telah ia mendapat pada segala kitab itoe dan bahoeasanja Allah soebhạnahoe wata' ālā tiada dapat tiada akan membangkitkan soeatoe jang bangsa (sic) Hāsjim lagi Ḳoeraisj lagi moelia lahir ia didalom Mekkah almoesjarrafah dan lagi membinasakan segala agama dan menjatakan agama islam dan iman daripada masjrik datang kemagrib dan tatkala melihat wazir itoe akan sifatnja jang seperti didalam kitab jang ta' loeknja (sic) itoe maka pertjahajalah ia dengandia wazir itoe dan sebeloem ada lahirnja dan zamannja itoe dan Allah Soebhānahoe wata'āla menjemboenjikan ia akan imānnja daripada segala kaoem keloearganja serta ra'iatnja sekaliam.

In de lithographie luidt dit kleine gedeelte als volgt: maka adalah iaitoe telak menilik pada segala kitab jang dahoeloe kala telah mendapat ia pada segala kitab itoe bahoeasanja Allah ta'ālā tiada dapat tiada akan membangkitkan akan soeatoe nabinja daripada bangsa Hasjim lagi Koeraisj lagi moelia lahir is didalam negeri Mekkah jang moesjarrafah dan lagi membinasakan segala hoekoem dan 
mentjatakan akan agama islam dan imān dari masjrik dan maghrib maka segala wazir itoe akan sifatnja jang seperti didalam kitab-kitab itoe jang ditiliknja itoe maka pertjajalah ia akandia wazir itoe sebeloem lahirnja dan zamannja dan memjemboenjikan ia akan imānnja daripada segala kaoem keloearganja dan ra'jatnja.

De gewone kleine verschillen, nauwelijk varianten te noemen, zooals tusschen twee of meer Maleische teksten steeds optreden, zijn ook in dezen passus op te merken; in overdaad van woordjes als akan en ada, achtervoegsels als $n j a$, en slordigheid van stijl komen beide specimina overeen, en zulks geldt van het geheele geschrift. Het gebrekkigst is de stijl van het H.S., bv. in de woorden dan bahoeasanja waarin dan overbodig is, soeatoe jang bangsa waarvoor de lithographie beter heeft: soeatoe nabinja darpada bangsa, en het geheel overbodige dan Allāh soebhānahoe wata'ála voor menjemboenjikan; tegenover deze feiten staat echter de fout in de lithographie dari masjrik dan maghrib die niet begaan is in het HS. dat heeft: daripada masjrik datang kemagrib. Een grove fout is (kitab jang) taloeknja, in plaats van ditiliknja, eene gewone slordigheid trouwens, immers in het begin stond reeds (telah) menilik, dus geen vertaalfout, daar in den Arabischen tekst niet staat ittaläa $a$, waaruit het woord ta 'loeknja wellicht zoude kunnen zijn verbasterd, maar: ra'a (2maal) en wa $\hat{g} a d a$.

Het zoude geen nut hebben op deze wijze den geheelen tekst in de beide specimina critisch te behandelen; een enkel voorbeeld moge voldoende zijn.

Een passus in HS. bl. 125 en lith. bl. 136 (voor het gemak van het overzicht, in twee kolommen).

\section{Handschrift.}

adapoen soengai jang lahir itoe maka iaitoe jang bernama Perat dan jang kedoeanja itoe soengai Nil dan soengai jang kedoea jang terseboet itoe maka iaitoe jang bernama Sihoen danlagi soengai jang kedoea itoe bernama Djihoen dan kedoea soengai tembaga daripada péhak negeri Roem arakian maka Saif Dal-Jazan poen masoeklah ia daripada pintoe koebah itoe ke-

\section{Lithographie.}

adapoen soengai jang lahir itoe bernama Perat dan jang kedoea soengai Nil dan soengai kedoea itoe berboenji bernama Sihoen dan Djihoen maka kedoeanja soengai itoe timboelnja daripada pèhak negeri Roem maka Saif al-Jazan poen masoeklah ia daripada pintoe $\mathrm{ka}$ bah kedalamnja maka dilihatnja didalamnja terlaloe besar dan koeat serta mérah tjahajanja 
dalamnja telah dapati didalamnja teramat besarnja daripada jang kota jang mèrah dan tjahajanja gilang-gemilang dan mengangkatken akan tjahajanja mata daripada sinarnja maka Saif Dal-Yazan poen naiklah diatas batoe itoe sembahjang doea rak'ah dan ia daripada mishaf Nabi Allāh Ibrahīm Chalil-Allah 'alaihi as-salām setelah soedah maka toeroenlah Saif Da'1-Jazan dari atas batoe itoe maka kembalilah ia keloear akan mendapatkan kepada Akasah. gilang-gemilang dan menghilangkan tjahaja mata daripada sinarnja maka Saif al-Jazan poen naiklah diatas batoe itoe sembahjang doea rak'ah salām dan membatjalah ia daripada sihaf nabi Allah Ibrahim Chalil Allah 'alaihi as-salam kemoedian maka Saif al-Jazan poen toeroenlah dari atas batoe itoe maka iapoen keloear mendapatkan Akasah.

De vergelijking tusschen deze twee passages bregnt geen verrassingen teweeg. De welbekende vier oude riviernamen zijn in de lith. iets beter dan in het HS. Berboenji moet semboenji zijn. Foutief is in het HS. de eigennaam Pr.n. voor Ferat. Even vreemd is daar het woord tombaga, blijkbaar eene inepte schrijffout voor timboel (Lith.). Waar het H.S. spreekt van een koepal (koebbah), heeft de.lith. ten onrechte $k a^{\prime} b a h$, wat te verklaren is uit het feit dat de Ka'bah in het aan dezen passus onmiddellijk voorafgaande enkele malen genoemd was. Onjuist is verder de lezing in de lith.: koeat i.p.v. kota; verkeerd is het woord dapati (H.S.), bedoeld is: didapatinja, evenals in de lith.: dilihatnja. Corrupt is de uitdrukking dan ia daripada mașhaf Nabi, wat te herstellen is uit membatjalah ia daripada sihaf Nabi in de lith. Dat H.S. den laatsten eigennaam Akasah spelt en de lith. Aksah is een onbeduidend verschil.

Over het algemeen is het H.S. gebrekkiger van spelling en zinsbouw, meer behept met zonderlinge fouten en op onkunde berustende verschrijvingen dan de lithographie.

Wat nu de verhouding tot den Arabischen tekst betreft, eene vergelijking met de Bulak-editie, dl. I, bl. 21 leert ons het volgende: terwijl in het Maleisch de verhaler (ar-rāwi) over de vier rivieren uitleg geeft, doet zulks in het Arabisch de "Zuster" Akisah, de dochter van den geestenkoning „De Witte”. De soengai jang lahir heeten ook hier 
nahrān lähirän, de vier namen zijn natuurlijk goed gespeld, en waar Mal. heeft: daripada péhak negeri Roem, biedt het Arab.: sāiraini ilā bilād at-Turk wa'r-Rum biiḍn Allāh Ta'alã al-hayy al-ḳayyum (berijmd prosa!). Het lezen uit het boek van Ibrahim den vriend Godes met een ,gebed" van twee rak'ah's wordt in het Arab. met nagenoeg dezelfde woorden verhaald (fatakaddama al-Malik Saif wawakafa watawada'a min phadihimā (nl. de twee rivieren) wașalla rak'ataini wa atammahoemā bi's-salāmi alā millati 'l-halīi Ibrahim 'alaihi as-salam). Deze parabellie duidt op nauwe verwantschap van beider model, of herleiding uit na-verwante bronnen, waarmede niet gezegd is dat men aan één „Ur-Saif” moet gelooven, immers daarvoor loopen de kunstige, ,,schöngeistige” stijl, en uitvoerige sierlijkheid van uitdrukking van het Arabische gewrocht en de stijllooze, gebrekkige vormgeving van het Maleische navolgingsproduct te zeer uiteen.

Waar in het Maleisch de koepel (koebbah) wordt beschreven met zijn rooden oogverblindenden glans, vinden we in het Arab. eene koebbah waar niemand was, noch witte noch zwarte (lam yakun 'indahā ahad wala fïha abyaḍ wa lā aswad), en waar zich een schitterende roode hyacinth bevond, welks glans den blik vasthield. Het benutten van den misşhaf (Lith. sihaf), het boek van Ibrāhīm, wordt in het Arab. evenzoo vermeld, nl. wa șa'ada ilā al lāhā wasallā rak'ataini faukalā wahuwe jatlū șuhuf Ibrahīm.

In het Arab. H.S. 1680 is de voorstelling veel-beknopter, ook omdat de stijl eenvoudiger is, en het den kunstvorm slechts bij uitzondering bezit. Daar staat slechts dit: hij bevond dat vier rivieren van onder den drempel (al-akabah) van den koepel stroomden, waarvan twee onmiddellijk onder de aarde verdwenen. De twee zichtbare rivieren alweer: $a z-z \bar{a} h i r a \bar{n}$ ) worden vrij goed, de onzichtbare nauwelijks met namen aangeduid; van de richting uit Roem wordt hier met dezelfde kortheid gewag gemaakt als in het Mal. Dit geldt ook van de scène der ontdekking van het inwendige der grot; er staat $\mathrm{nl}$. slechts (bl. 44): hij trad den koepel binnen, en vond in het midden een grooten steen van rooden hyacinth, welks glans de blikken vasthield. Daarna klom hij er op, ,bad” twee rak'ah's, en las in de bladzijden van Ibrāhīm (dezelfde woorden als in de editie-Kairo). Ex uno disce omnia!

$\mathrm{Nu}$ iets over het slot. $\mathrm{Na}$ beschrijving eener scène, die aan Maleische lezers wel zeer aangenaam bekend moet zijn, nl. die der kunst van vliegen door middel van een vlieg-badjoe, ook in de Javaansche, 
Minangkabousche en Bataksche literatuur zoo gewoon en populair, wordt verhaald dat Saif, volgens zijne belofte na vijf dagen afwezigheid van de jacht teruggekomen, de menschen in zijne stad ziet rouwen, en verneemt dat zijne echtgenoote met haar kind verdwenen is. Hij bezwijmt, doch wordt weder bijgebracht, en erlangt hulp van zijne vriendin 'Akisah; zij wil geen gevolg geven aan zijne bede om hem naar de stad zijner vrouw, Moenjat an-Noefoēs, waar geen man mocht vertoeven op straffe van gruwelijken dood, te brengen, waarop hij weende ,als een kind”, en op zich nam afstand van de regeering te doen, na welke belofte hij door haar al vliegende naar de begeerde stede, tevens gevangenis, gebracht wordt. Weldra komt de zwarte rotsstad in zicht. Vooraf gaat zij er heen om een kleed zooals de vrouwen daar dragen en een strik zooals zij er gebruiken, aan Saif te brengen, opdat hij zich daarmede tooie, en zoo op de bewoonsters kan gelijken. Spoedig zullen zij allen komen aanzwermen onder aanvoering van hare vorstin Noer al-Hoedā ${ }^{1}$ ) (de zuster van Moenjat annoefoes); ,ze omvatten elkaar in vurige omhelzingen om zoo den liefdedrift te koelen”, zoo waarschuwt zij hem, ,en zullen ook U benaderen, maar als eene vrouw uw geslacht ontdekt, moet ge in hare vingers bijten (in de lith.: moet ge hare vingers even vastbinden), waardaar zij zich zich verplicht zal voelen $U$ den weg te wijzen. Dezen raad volgt hij, op zijn levensbehoud bedacht. Inderdaad nadert hem de aanvoerster, Fardjanah, Lith. Mardjanah, voelt in de omhelzing zijne mannelijkheid, stelt hem naar de afspraak in de gelegenheid zijne echtgenoote te ontmoeten, waarop eene aandoenlijke scène volgt. Zijne als overtreding te beschouwen aanwezigheid in de vrouwenstad, tevens gevangenis zijner echtgenoote, wordt hem vergeven. Hij verkrijgt vrijgeleide en zekerheid van leven en goederen, toovert met zijne wondertafel (loẹ) den trouwen geest 'Airoed te voorschijn, die hem met vrouw en kind naar zijn eigen land terugbrengt. Alles was dus pais en vree, zijn land nam in bloei en aanzien toe, alle inwoners baden voor het heil hunner voor goed terug gekomen koninklijke familie.

Dit besluit is geheel en al naar het model der tallooze Maleische hikajats, die alle eindigen met eene algemeene verzoening, eene begenadiging der vorstelijke schakers door de ouders hunner bruiden, de vestiging in hun vaderland, en een idyllisch leven der na vele avonturen in hun stamland teruggekomen vorstelijke familie.

1) Ook: Nōer al-Hādĩ. 
Dan volgt nog de dateering, in het H.S. zonder jaar, in de lith. met het jaar, nl. 1311 (1894), en met de melding dat de beëindiging in dat jaar op 19 Moeharram plaats vond tijdens het bewind van Sajjid Zain Bin Pangéran Sjarif 'Ali Bin Al-Habib Pangeran Sjarif Hoesain Bin Sjihabaddin, blijkbaar vorst van een Maleisch land, waarschijnlijk Riouw.

Schijnbaar is hiermede het verhaal geëindigd. Evenwel, van allerlei daarin voorkomende personen wordt niets meer vermeld, en eene vergelijking met den Arabischen tekst doet blijken dat deze scène geenszins het slot vormt van het geheel, maar vrijwel van de vijfde der 17 djoez' waarin het werk verdeeld is. Het tooneel van het balen baton-spel staat in de Kairo editie op bl. 60 van deel 5 ; de schildering der door de onstuimige aanrakingen met de vrouwen opgewekte hartstocht der zinnen, de wulpschheid der gevoelens, en de ontembare drift van den libido sexualis, worden met eene uitvoerigheid verhaald, welker uitgesponnenheid voor ons slechts ten deele wordt gecompenseerd door den woordenrijkdom en den kunstigen stijlvorm van het nooit verzaakte genre der prose rimée, welks qualiteiten nog verhoogd worden door de fraaie verzen, waarin de hoofdpersoon zijne gevoelens tot uitting brengt, benevens de sierlijke poëtische beantwoording daarvan door de gemalin.

Tot in het zesde deel gaat de beschrijving der bevrijding van de gevangenen, de onttoovering der beheksten, en der verzoening tusschen de gemalin en hare ouders voort. Eindelijk komt de alomtegenwoordige Aboe'l-'Abbās al-Chidr te voorschijn om Saif te nopen de geloofsbelijdenis (,er is geen God dan Allāh en Ibrahīm is de vriend van Allāh") uittespreken, en al zijne wazieren den islam te doen aannemen. Als eindelijk zijne ontmoeting met zijn schoonvader plaats vindt, blijkt ook deze het ware geloof te hebben aangenomen, zoodat geenerlei vijandschap tusschen hen meer kan bestaan. $\mathrm{Nu}$ gaat in vrede elk zijns weegs, naar Mișr en de Wāk-al-wāk-eilanden, welke mythische contreiën uit de literatuur der wonderverhalen, o.a. de 'Adjāib al-Hind, welbekend zijn.

Ten lagen leste bereikt de beschrijving der gebeurtenissen, die de vestiging van Saif in zijn land vergezelden, haar einde, en dit (op bl. 13 van deel VI) valt nagenoeg samen met het besluit der Maleische teksten.

Het verlossende woordenpaar kala ar-rāzer (in Mal. verhalven, ook in de Sadjarah Melajoe met kata rāwī weergegeven) op bl. $13 \mathrm{r}$. 8 kondigt aan dat de geschiedenis van 'Akisah, de dochter van den 
witten 'Airoed, den zoon van den rooden geestenvorst, aan de beurt van behandeling is.

Dit was inderdaad een geschikt punt voor den Maleischen bewerker om aan de geschiedenis een eind te maken; het is de vraag of zijne lezers de afwezigheid van het relaas der avonturen van de vele figuranten in het groote verhaal als een gemis zullen hebben gevoeld. De roman is feitelijk niet af, maar wat ervan bekend gemaakt was heeft de lezers, die wellicht slechts zéér weinigen geweest zijn, voldoende afleiding en vermaak verschaft. Op belangstelling bij hen voor een nóg uitvoeriger boek, zooals de indertijd in den Indischen Archipel zoo populaire Hikajat Amir Ḥamzah, kon de „redacteur”, die zijn volk in dat opzicht zeker wel kende, niet rekenen.

Ook in de Bataviasche HSS. wordt de onvoltooide tekst aangetroffen; in één ervan (zie Catalogus-HS, v. h. Batav. Gen. v. K. en W. bl. 626) wordt er aan toegevoegd: ,er is nóg een verhaal van de Zonen Saif's, zoek dat als ge er naar verlangt; er bestaat voorts nog een verhaal van hunne spruiten, dat zijn dus de kleinzonen van Saif den Himjarietischen koning".

Of dat vervolg werkelijk bestaat als in handschrift opgeteekende tekst is onbekend, en naar het ons voorkomt niet waarschijnlijk te achten. Er zal geen ,vraag” naar de rest geweest zijn, en van het feit dat de bewerker is teruggeschrikt voor eene voortzetting der vertaling (s.v.v.) van de overstelpend-reusachtige stof, heeft de uitgever der lithographie, evenals de redacteur (wederom s.v.v.) van de HSS., gebruik gemaakt om den torso als afgerond verhaal onder het publiek te brengen.

Dat er in de collectie-v. Dewall niet minder dan vier HSS. van ons verhaal voorkomen behoeft niet op frequentie in Maleische kringen te wijzen. Het eendere formaat geeft aan: dat de verzamelaar-van-Gouvernementswege hem aangebodene exemplaren heeft laten copiëeren op zijn folio-papier; toen ruchtbaar werd dat een belangstellende teksten wilde aanschaffen, heeft men zich gehaast wat men krijgen kon in te leveren, of copieën te vervaardigen van origineelen, die de bezitters bleven behouden, om zóó hun bezit productief te maken. Evenwel, van veel belang is deze quaestie niet.

Ook H. C. Klinkert heeft een exemplaar laten copieëren door zijn' schrijver, van wiens hand zoovele zijner in dienst van het Bijbelgenootschap verzamelde HSS. herkomstig zijn, en die blijkbaar voor die taak niet de vereischte eruditie had. De chef der steendrukkerij Hadji Amin, die den copiïst Moeḥammad Hasan Bin Hadji 
Moehammad Djan (?) den voor dezen niet gemakkelijken, door de vele vreemde woorden zelfs zeer moeilijken, tekst op steen liet schrijven, kende den smaak van zijn publiek, beloofde aan het slot nog meer van dergelijke lectuur, en liet zóó een product verschijnen dat een zeker, zij 't ook kortstondig, succes, en eenige verspreiding moet hebben gehad.

Dat de Maleische hikajat uit het Arabisch vertaald is, is boven allen twijfel; dat ze uit een tekst overeenkomende met codex 1680 is overgezet is niet bewezen, maar dat ze daarmede zeer nauwe verwantschap heeft, én in de opvolging der episodes én in het gebruiken van speciale termen en uitdrukkingen, kan uit eene vergelijking der beide schrifturen blijken, gelijk ook uit de enkele bovenmedegedeelde pericopes duidelijk werd.

Ze behoort, 't is bijna overbodig het te betoogen, tot de ArabischeMaleische navolgings-literatuur, en vormt daarin een eigenaardig specimen. Wie de bewerker is, is als gewoonlijk, onbekend. Een Maleier, die zooveel Arabisch kende dat hij tot vertalen, althans tot bewerken, der materie in zijne taal in staat was, is als figuur denkbaar, ook eene halve eeuw geleden. Maar waarschijnlijker is de figuur van een in Maleische landen geboren Arabier, al of niet van een inlandsche moeder, die genoeg Arabisch kende om een verhaal in die taal te kunnen lezen, en van het Maleisch genoeg wist, om zich in deze taal, zij 't gebrekkig, uit te drukken. Deze soort ,vertalers”, 't best als 'Arab peranakan aan te duiden, is in 't algemeen als de catagorie van bewerkers der uit het Arabisch herkomstige Maleische geschriften te beschouwen.

Maar de tekst van een HS. als dat van Klinkert, en van een steendruk als die van Singapoera is zeker niet het eigen werk van zulk een ,,auteur"; daarvoor zijn de Arabische woorden te sterk verknoeid, en de Arabische eigennamen te zeer misvormd. Van zijn goed bedoelde poging biedt de Maleische ,redactie”, zooals die voor ons ligt, slechts een verworden, verbasterd, bedorven beeld.

Uit de Maleische teksten, ook uit de Bataviasche, één textus receptior samen te stellen is niet mogelijk; daartoe verschillen ze in kleinigheiden te veel. Hoogstens zoude één tekst - maar welke? als grondslag genomen kunnen worden, en daarbij als variae lectiones de afwijkende „Lezingen” in noten te vermelden zijn, een werk dat een verhaal als het onze, met zijn geringe historische en islamologische beteekenis, eigenlijk niet waard is, vooral omdat het reeds vroeger in tegenstelling met de verhalen van „Amir Ḥamzah” en 
„De duizend vragen”, om slechts diè te noemen, weinig bekendheid genoot, en tegenwoordig uit den kring van die literatuurproducten, welke zich in eenige populariteit kunnen verheugen, geheel verdwenen is.

Toch was het o.i. geen overbodig werk dit verhaal in zijne betrekking tot de Arabische modellen of bronnen tot onderwerp eener verhandeling te nemen, en daarmede aan een schakel in de catena der Mohammedaansche Maleische literatuur-produçten, beschrijving en toelichting te doen geworden. 